\title{
STRATEGI ADAPTASI DARI KEBENCANAAN STUDI KASUS STRUKTUR DAN LINGKUNGAN SITUS GUNUNG PADANG
}

\author{
Disaster Adaptation Strategies \\ Case Studies on Structure and Environment of Gunung Padang Site \\ Lutfi Yondri $^{1}$ \& Danny Zulkifli Herman² \\ ${ }^{1}$ Balai Arkeologi Jawa Barat \\ Jalan Raya Cinunuk Km.17 Cileunyi, Kabupaten Bandung 40623 \\ ${ }^{2}$ Ahli Geologi Pensiunan Museum Geologi Bandung \\ Jalan Tubagus Ismail Gg, Virgo No. 13. Bandung \\ E-mail: yondrilutfi@gmail.com
}

\begin{abstract}
The stone structure of the Gunung Padang site until now can be recorded as one of the structures built by prehistoric society for the ancestor in the past. Located in height known as Gunung Padang. One aspect that has not been much discussed until now is how the insecurity of its structure and environment that has long been in the fault line of Cimandiri and Cikondang and placed in a landslide-prone location. This paper aims to explore the potential and track record of the threat of damage that occurred in the past to the present, and how the society that built the structure anticipated it. It tried to observe based on the pattern of stacking rocks forming structures and observation of various elements that are new formations around the slopes that are young associated with disaster records obtained from literary sources. Based on studies result can be concluded that the community has been wise and good at composing stone blocks that shape the structure that anticipatory to the state of the environment in the past.
\end{abstract}

Keywords: technology, construction, stacking patterns, and adaptation.

\begin{abstract}
Abstrak
Punden Berundak Gunung Padang sampai sekarang dapat dicatat sebagai salah satu struktur yang di bangun oleh masyarakat prasejarah untuk kepentingan pengagungan arwah leluhur di satu tinggian yang kemudian disebut sebagai Gunung Padang. Salah satu aspek yang belum banyak dibahas hingga kini adalah bagaimana kerawanan struktur dan lingkungannya yang sejak dulu berada di jalur sesar akif Cimandiri dan Cikondang, serta berada di lokasi yang rawan longsor. Tulisan ini bertujuan mengeksplorasi tentang potensi dan rekam jejak ancaman kerusakan yang terjadi pada masa lalu hingga kini, dan bagaimana masyarakat pendiri struktur punden berundak Gunung Padang dalam mengantisipasinya pada masa lalu Untuk membahas hal tersebut dicoba amati pola susun batuan pembentuk struktur punden dan pengamatan berbagai elemen yang merupakan bentukan baru di sekitar lereng yang kemudain dikaitkan dengan catatan kebencanaan yang diperoleh dari sumber literatut. Dari hail kajian dapat disimpulkan bahwa masyarakat yang membangun punden berundak tersebut telah arif dan pandai menyusun balok-balok batu pembentuk struktur tersebut yang antisipatif terhadap keadaan lingkungannya pada masa lalu.
\end{abstract}

Kata kunci : teknologi, konstruksi, pola susun, dan adaptasi 


\section{PENDAHULUAN}

Punden berundak Gunung Padang sampai sekarang dapat dicatat sebagai salah satu struktur punden berundak yang terbesar di kawasan Nusantara. Tinggalan ini merupakan hasil penemuan kembali pada tahun 1979 oleh para petani Endi, Soma dan Abidin. Sebelumnya tinggalan ini pernah dicatat pada tahun 1891 oleh DR. R. D. M. Verbeek dalam Verhandelingen van Het Bataviaasch Genootschap der Kunsten en Wetenschappen, Deel XLVI, diterbitkan oleh Lansdrukkerij Batavia - M Nijhoff's Hage tahun 1891. Pada poin yang ke 38. Goenoeng Padang. District Peser, afdeeling Tjiandjoer, Blad K. XIII. "Op den bergtop Goenoeng Padang, nabij Goenoeng mélati, eene opeenvolging van 4 terrassen, door trappen van ruwe steenen verbonden, met ruwe platte steenen bevloerd en met talrijke scherpe en zuilvórmige rechtopstaande andesietsteenen versierd. Op ieder terras een heuveltje, waarschijnlijk een graf, met steenen omzet en bedekt, en van boven met 2 spitse steenen voorzien. In 1890 door den heer De Corte bezocht (Verbeek, 1891).

Pencatatan lebih lanjut tentang Situs Gunung Padang juga dilakukan oleh NJ. Krom dalam Rapporten Oudheidkundige Dients yang ditulisnya pada tahun 1914. Krom menulis tentang bangunan berundak Gunung Padang tersebut tertutup oleh hutan dan semak belukar (Krom, 1915). Sejak penemuan kembali pada tahun 1979, berturut-turut telah dilakukan penelitian oleh tim baik dari Direktorat P3SP maupun dari PUSPAN (saat sekarang bernama Pusat Penelitian dan Pengembangan Arkeologi Nasinal), serta Balai Arkeologi Bandung selaku instansi yang menangani penelitian arkeologi di daerah.

Secara administratif Situs Gunung Padang termasuk dalam wilayah administratif Desa Karyamukti, Kecamatan Campaka, Kabupaten Cianjur. Secara geografis kawasan ini terletak antara $6^{\circ} .57^{\prime} \mathrm{LS}$ dan $107^{\circ} .01^{\prime}$ BT. Berada di antara dua kampung, yaitu Gunung Padang di sebelah timur dan Cipanggulan di sebelah barat. Untuk mencapai situs dari Kota Cianjur, dapat ditempuh melalui dua arah, yaitu dari arah barat dan timur. Dari arah barat: Cianjur - Sukaraja - Tegal Sereh - Gunung Padang. Kondisi jalan antara Cianjur Sukaraja - Tegal Sereh beraspal, sedangkan dari Tegal Sereh ke Situs Gunung Padang kondisi jalannya belum diperkeras. Dari arah timur, Cianjur - Warung Kondang Cikancana Lampegan - Pal Dua - Gunung Padang dengan jarak tempuh sekitar 25 km. Kondisi jalan antara Cianjur - Warung Kondang - Cikancana - Pal Dua beraspal. Dari Pal Dua ke Situs Gunung Padang kondisi jalannya saat sekarang sebagian sudah beraspal (Yondri, 2016).

Punden berundak Gunung Padang kembali muncul dalam penelitian arkeologi seperti yang dikemukakan oleh Haris Sukendar (1985) dalam tulisannya yang berjudul Album Megalitik Kabupaten Cianjur, terjadi sekitar tahun 1979, setelah tiga warga masyarakat (Endi, Soma, dan Abidin) menemukan reruntuhan batuan yang terkandung dalam semak belukar di bukit Gunung Padang dan kemudian melaporkan peristiwa itu kepada Penilik Kebudayaan Kecamatan Campaka.(Sukendar, 1985) Sejak itulah kemudian berturut-turut tim peneliti baik dari Direktorat Perlindungan Pembinaan Peninggalan 
Sejarah dan Purbakala (DP3SP) maupun dari Pusat Penelitian Arkeologi Nasional mengadakan kegiatan lapangan baik berupa pemetaan, penggambaran, maupun pendeskripsian tinggalan.

Sampai sekarang dapat dicatat bahwa punden berundak Gunung Padang telah banyak menarik perhatian para ahli, hal ini mungkin disebabkan karena masih banyak pengetahuan tentang kemasalaluannya yang belum tergali hingga kini. Salah satu aspek yang cukup menarik untuk didiskusikan adalah bagaimana kaitan tinggalan tersebut dengan sejarah panjang struktur dan lingkungannya. Terutama bagaimana struktur itu dibangun oleh masyarakat masa lalu yang berhadapan dengan lingkungan yang rawan akan bencana. Untuk mengurai permasalahan tersebut digunakan metode deskriptif-eksplanatif yang diterapkan dari temuan-temuan yang diperoleh baik dari kajian hasil penelitian lapangan maupun dari kepustakaan.

\section{PEMBAHASAN}

Bila diamati secara seksama dari bentuk dan perubahan yang terjadi pada susunan batu penyusun punden berundak dan juga keadaan lingkungan Situs Gunung Padang terdapat rekam jejak kebencanaan yang pernah terjadi pada masa lalu. Bencana tersebut dapat dikategorikan sebagai bencana geologis, non geologis, serta bencana akibat ulah manusia. Bencana alam geologis di antaranya gempa bumi, tanah longsor, dan banjir. Bencana alam non geologis seperti angin kencang (badai, puting beliung), petir, dan lainlain. Sementara itu, bencana sebagai akibat ulah manusia misalnya bencana sebagai akibat perilaku budaya, konflik sosial, masalah hukum dan ekonomi.

\section{Bencana Alam Geologis}

Bencana alam geologis di Situs Gunung Padang terdiri dari longsor dan gempa bumi. Bahaya longsor yang terjadi di lingkungan Situs Gunung Padang tidak lepas dari keletakannya secara regional merupakan bagian dari daerah Cianjur bagian selatan yang rentan terhadap tanah longsor. Tanah longsor di daerah gunung api, terutama yang dipicu oleh adanya batuan ubahan hidrotermal dan lapisan tanah purba. Sementara itu, gempa bumi di lingkungan situs dapat disebabkan oleh gerakan tektonik, terutama dari sesar aktif Cimandiri yang berpotongan dengan sesar Gede - Cikondang (Sutikno Bronto dan Billy S. Langi, 2016).

Berdasarkan hasil penelusuran data gempa yang bersumber dari USGS (United States of Geological Survey) dan BKMG (Badan Klimatologi, Meteorologi dan Geofisika) diketahui bahwa di daerah Cianjur, yang berdekatan dengan Gunung Padang, sering terjadi gempa bumi, baik bermagnituda besar (> $5 \mathrm{SR} / \mathrm{Skala}$ Richter) maupun bermagnituda kecil $(<5$ SR). Beberapa gempa bumi tektonik berskala besar di daerah itu ditampilkan pada tabel berikut (Tabel 1). 
Tabel 1. Catatan Kejadian Gempa Bumi di Kabupaten Cianjur

\begin{tabular}{|c|c|c|c|}
\hline Nomer & Waktu Kejadian & $\begin{array}{c}\text { Koordinat\& Kedalaman Sumber } \\
\text { Gempa }\end{array}$ & Magnituda \\
\hline 1 & 10 Oktober 1834 & - & VIII - IX MMI \\
\hline 2 & 25 Mei 1843 & - & VII - VIII MMI \\
\hline 3 & 15 Februari 1852 & - & VII - VIII MMI \\
\hline 4 & 30 Desember 1852 & - & VIII - IX MMI \\
\hline \multirow[t]{2}{*}{5} & 10 Februari 1982, & $6,86^{\circ} \mathrm{LS}-106,93^{\circ} \mathrm{BT}$ & $5,5 \mathrm{SR}$ \\
\hline & pk. 23:17:51 wib & $3,9 \mathrm{~km}$ & \\
\hline \multirow[t]{2}{*}{6} & 9 Oktober 1985 , & $6,74^{\circ} \mathrm{LS}-107,00^{\circ} \mathrm{BT}$ & $6,4 \mathrm{SR}$ \\
\hline & Pk. 08:15:06 wib & $156 \mathrm{~km}$ & \\
\hline
\end{tabular}

Sumber: Bronto dan Langi 2012

Meskipun belum ada pemantauan dan pencatatan secara rinci, diperkirakan sesar aktif Cimandiri dan Gede-Cikondang dapat pula menimbulkan gempa bumi tektonik mikro di daerah Gunung Padang dan sekitarnya. Kombinasi gempa bumi tektonik dan batuan ubahan hidrotermal, sebagai faktor dari dalam (endogen), dengan faktor dari luar (eksogen), seperti halnya curah hujan, pelapukan cuaca, erosi, relief kasar (lereng curam) dan aktivitas manusia, menjadi penyebab daerah Gunung Padang dan sekitarnya sangat rentan terjadi gerakan tanah atau longsoran (Bronto, 2012). Kemudian Berdasarkan bentuk bentang alam dan sifat fisik serta keteknikan batuan dan tanah, Suhirman dan Gustiar (1993) menyatakan bahwa kawasan Gunung Padang dan sekitarnya merupakan wilayah yang rentan terhadap gerakan tanah atau longsoran. Bentang alam daerah tersebut merupakan pebukitan tinggi berlereng curam (lereng > $40 \%$ ). Batuan penyusun terdiri atas breksi, tuf dan batupasir kompak dan keras tetapi berkekar dan mudah pecah. Tanah pelapukan (termasuk batuan ubahan hidrotermal) bersifat lunak, plastis, rapuh, dan mudah hancur bila kering. Penampakan bentang alam dan sifat batuan serta tanah tersebut sangat rentan gerakan tanah atau tanah longsor pada musim hujan.

Mengacu kepada hasil pengamatan di lapangan bahwa batuan dasar yang ditumpangi kekar kolom lava andesit Gunung Padang (penyusun situs punden) adalah dominan ubahan lempungan asal batuan volkanik, maka patut diduga dapat memiliki sifat plastisitas tinggi yang memungkinkan berakibat penurunan stabilitas lereng di wilayah tersebut (Herman, DZ. 2017). Lereng di sekitar G.Padang dimana Situs Punden berada tersusun oleh tanah lempung ekspansif yang rentan terhadap gerakan tanah terutama pada saat musim hujan.

Tanah longsor tidak hanya di Gunung Padang tetapi juga terjadi di banyak tempat yang lain, yang berlereng terjal dan tersusun oleh batuan ubahan hidrotermal. Sebagai contoh longsor di sepanjang jalan Paldua - Gunung Padang, jalan Paldua - Cikondang, lereng Pasir Malang, dan lereng dalam (utara) Pasir Empet - Malati. Menurut para petugas Situs Gunung Padang (komunikasi lisan), yang bekerja di situs itu sejak tahun 2010, setiap 
musim hujan hampir selalu terjadi tanah longsor di daerah tersebut. Berdasarkan informasi itu serta waktu kejadian, fenomena longsoran di Gunung Padang dapat dikelompokkan menjadi dua bagian, yaitu longsoran lama dan longsoran baru. Longsoran lama terjadi sebelum tahun 2010, sedangkan longsoran baru terjadi sesudah 2010. Longsoran lama teridentifikasi pada jalan masuk dari Dusun Cimanggu ke Gunung Padang, lereng utara, serta lereng timur-tenggara. Selanjutnya, meskipun sudah dibangun tembok, pada bagian atas masih terdapat campuran tanah lempung berwarna coklat kemerahan dengan bongkah batu kolom. Di lereng utara gejala longsoran terdapat di dua lokasi, yakni di utara/bawah jalan dan di dekat lokasi parkir atas atau di samping tangga naik/pintu masuk ke puncak Gunung Padang.

Di lokasi pertama batu kolom roboh dengan sumbu panjangnya searah bidang lereng. Batu kolom itu menyatu dengan tanah lempung berwarna coklat kemerahan Di samping tangga naik ke puncak Gunung Padang juga tersingkap tiga lapisan endapan longsoran. Masing-masing endapan longsoran terdiri atas tanah lempung putih bercampur dengan bongkah batu kolom. Tanah lempung putih itu adalah kaolin atau argilik sebagai hasil ubahan hidrotermal pada masa lampau sewaktu Gunung api Karyamukti masih aktif, atau paling tidak magmanya sedang mengalami pendinginan. Bongkah batu kolom merupakan bagian dari kubah lava Gunung Padang yang sudah roboh berserakan dan kemudian ikut longsor ke lereng bahkan sampai di kaki Gunung Padang.

Bagian permukaan lapisan endapan longsoran terbawah (el-1) dan menengah (el-2) sudah menjadi tanah purba (paleosols), sedangkan endapan longsoran teratas (el-3) langsung ditutupi oleh tanah permukaan sekarang (topsoil). Tanah purba pertama menunjukkan bahwa pada masa lampau tanah itu terbentuk di permukaan sebagai akibat proses pelapukan cuaca. Namun kemudian tanah itu tertimbun oleh endapan longsoran kedua, yang lama kelamaan bagian permukaannya juga melapuk menjadi tanah. Selanjutnya endapan longsoran kedua ini juga tertimbun oleh endapan longsoran ketiga sampai dengan sekarang ini.

Keberulangan longsoran tersebut juga tergambar dari uji pertanggalan sampel hasil pengeboran yang dilakukan oleh Tim Terpadu Riset Mandiri (TTRM) Gunung Padang dengan analisis pertanggalan dari Batan, BetaLab (Yondri, 2016). Hal itu juga jelas terlihat di sisi yang lain. Di lereng timur-tenggara endapan longsoran lama teramati dengan baik di tepi jalan dari Dusun Cimanggu sampai Dusun Cikuta dan di hulu Ci Kuta Bahan longsoran lama ini relatif sama dengan pada lereng Gunung Padang yang lain, yaitu terdiri atas campuran tanah lempung merah coklat dengan bongkah-bongkah batu kolom bersusunan andesit basal. Di lereng timur-tenggara ini juga teramati bahwa struktur memanjang batu kolom miring searah dengan bidang lereng, yakni ke arah timur-tenggara. Endapan longsoran baru juga terjadi di beberapa lokasi pada lereng utara, timur dan barat dari Gunung Padang. Pada lereng utara, di lokasi parkir atas dan sebelah baratnya longsoran terjadi pada musim hujan akhir tahun 2011 - awal 2012. D kaki Gunung Padang sebelah 
barat, yakni di Dusun Cipanggulaan, longsoran batuan ubahan hidrotermal yang membentuk tanah lempung berwarna merah kecoklatan terjadi pada 14 November 2014. Longsoran baru ini juga menimpa rumah penduduk di Dusun Cimanggu atas dan Cikuta.

Di dasar selokan, tepi jalan Dusun Cikuta, tersingkap batuan dasar berupa batuan ubahan hidrotermal berwarna putih abu-abu. Berdasarkan teksturnya diperkirakan batuan itu adalah andesit (basal?), yang lebih tua dan diterobos oleh magma pembentuk kubah lava Gunung Padang. Batuan beku andesit terubah ini agaknya menjadi lebih lunak dan tidak lulus air sehingga berperan sebagai dasar bidang gelincir terhadap material di atasnya, yang berupa tanah lempung merah coklat bercampur dengan batu kolom. Sementara itu, bidang longsoran di belakang rumah penduduk Dusun Cikuta dapat diamati adanya tiga endapan longsoran tua; lapisan terbawah dan menengah sudah membentuk tanah purba. Lapisan endapan longsoran teratas bagian bawah berwarna putih tersusun oleh tanah lempung putih sebagai hasil ubahan hidrotermal, bercampur dengan bongkah batu andesit keras, dan ke atas berangsur menjadi lempung merah coklat sebagai tanah penutup permukaan (top soil).

Longsoran baru tidak hanya terjadi pada lereng bawah dan kaki, tetapi juga terjadi pada lereng atas bagian barat, yang sangat dekat dengan puncak Gunung Padang. Di bidang longsoran nampak ada dua lapisan endapan longsoran. Lapisan endapan longsoran bawah tersusun oleh batuan yang sudah sangat lapuk berwarna putih kemerahan, merah abu-abu sampai dengan merah coklat, tetapi masih teridentifikasi sebagai batuan beku berstruktur kulit bawang. Inti struktur kulit bawang ada yang masih keras, tetapi banyak juga yang sudah lunak karena pelapukan, atau bahkan sudah hilang tererosi. Sebaliknya pada lapisan atas struktur batu kolom masih nampak jelas, meskipun sebagian juga lapuk mengulit bawang di antara tanah lempung pelapukan. Secara vertikal ke atas batu kolom pada lapisan kedua ini semakin sedikit, sedangkan tanah lempung pelapukan semakin banyak. Diperkirakan pada saat terjadi longsoran batu kolom, karena beratnya, lebih terkonsentrasi di bagian bawah endapan. Sementara di bagian atas berupa material yang lebih ringan, yaitu tanah lempung pelapukan. Selain bencana gempa bumi dan longsor, dimungkinkan juga adanya hujan abu gunung api yang jatuh menutupi batuan Situs Gunung Padang. Reaksi dari abu api dan air hujan dapat juga menyebabkan dampak negatif terhadap Situs Gunung Padang.

Dari uraian tersebut di atas dapat diketahui bahwa faktor pengontrol terjadinya gerakan massa tanah dan batuan di Gunung Padang adalah lereng terjal $\left(20^{\circ}-40^{\circ}\right)$, tanah lempung, batu kolom andesit basal, struktur geologi, dan curah hujan. Tanah lempung berwarna putih (kaolin/argilik) sebagai hasil ubahan hidrotermal, tetapi setelah tersingkap di permukaan dan mengalami proses pelapukan lanjut oleh cuaca warnanya berubah menjadi merah dan kemudian coklat kemerahan. Ke bawah permukaan tanah lempung putih ini diduga sangat tebal karena memang terbentuk oleh proses hidrotermal dari dalam bumi (Bronto dan Langi, 2016). Pada awalnya tanah lempung putih - coklat kemerahan tersebut ditumpangi oleh batu kolom yang sudah roboh berserakan di permukaan. Air hujan 
yang jatuh di puncak dan lereng Gunung Padang masuk ke dalam tanah melalui tumpukan batu kolom yang roboh berserakan dan rekahan serta retakan pada tanah lempung menyebabkan tanah lempung itu menjadi jenuh air dan terbebani oleh batu kolom yang menindih di atasnya di daerah puncak dan lereng Gunung Padang. Hal itu menyebabkan terjadinya pengurangan kuat geser serta peningkatan tegangan geser pada tanah, dan setelah melalui kondisi kritis terjadilah gerakan massa tanah dan batuan menuruni lereng Gunung Padang. Berhubung gerakan massa itu cepat, pada kelerengan terjal, dan endapannya berada dekat di lereng bawah - kaki gunung, yang sering melanda rumah penduduk dikelompokkan ke dalam longsoran, nendatan atau luncuran. Dengan demikian sebagai pemicu utama longsoran ini adalah air hujan dan pemicu tambahan adalah pembebanan yang berlebihan oleh batu kolom yang telah roboh berserakan di atas tanah lempung. Pemicu tambahan yang lain mungkin adalah gempa bumi (mikro), sekalipun hal ini masih diperlukan pemantauan lebih cermat.

Memperhatikan fenomena longsoran di Gunung Padang pada umumnya mempunyai bentuk bidang longsor melengkung. Longsoran lereng ini bertipe longsoran rotasi (rotational slides). Penampakan longsoran di Gunung Padang ada yang tua ada yang muda. Longsoran tua terjadi berulang kali dan di permukaannya ada yang telah terbentuk tanah purba. Data ini menunjukkan bahwa endapan longsoran lama dapat melongsor lagi secara berkali-kali. Longsoran yang terjadi berulang kali ini dinamakan multiple rotational slides. Menurut Skempton (1969) longsoran rotasi berulang-ulang banyak terjadi pada suatu lereng tanah yang retak-retak dan bagian atasnya terdapat lapisan batuan atau tanah yang lebih padu. Pendapat ini sesuai dengan kondisi di Gunung Padang, yang permukaannya tersusun oleh tanah lempung dan batuan retak-retak ditumpangi oleh (lapisan) robohan batu kolom (Skempton, A. 1969).

Peristiwa gerakan massa tanah dan batuan merupakan fenomena alam, yaitu alam mencari keseimbangan baru akibat adanya gangguan atau faktor yang mempengaruhinya. Di Gunung Padang gerakan massa ini telah terjadi berulang kali hampir pada semua lereng (utara, barat dan timur). Berdasarkan data longsoran pada lereng atas bagian barat, yang sangat dekat dengan puncak Gunung Padang, serta pola sebaran longsoran di lereng menuju hampir ke segala arah, diperkirakan bahwa situs Punden Berundak dibangun di atas endapan longsoran sangat tua atau telah terjadi sebelumnya (Sutikno, 2012). Hal ini juga dengan pertimbangan bahwa kubah lava Gunung Padang sudah terbentuk jutaan tahun yang lalu (>2 jtl.; Pliosen), sementara pembangunan Punden Berundak oleh manusia masa lalu baru berlangsung 2.000 tahun yang lalu (Yondri, 2019). Pada kurun waktu antara dua juta tahun yang lalu dengan beberapa ribu tahun yang lalu pasti telah banyak terjadi peristiwa geologi atau dinamika bumi, baik oleh faktor endogen maupun eksogen, yang menyebabkan robohnya kubah lava berstruktur kekar kolom dan gerakan massa tanah serta batuan di Gunung Padang. 


\section{Bencana Alam Non-Geologis}

Bencana alam non-geologis atau bencana alam atmosfer terdiri dari angin kencang (badai, puting beliung), petir dan lain-lain. Berhubung kawasan Gunung Padang merupakan daerah terbuka dan berbukit, maka kondisi itu memungkinkan dapat terjadi bencana angin kencang dan petir terutama pada waktu peralihan musim (pancaroba). Kekurangan air bersih terutama pada musim kemarau juga dapat dipandang sebagai musibah yang perlu diperhatikan. Tanah penyusun kawasan Gunung Padang sangat didominasi oleh tanah lempung sebagai hasil ubahan hidrotermal. Tanah lempung itu berukuran sangat halus dan sangat tebal serta tidak dapat berfungsi sebagai lapisan pembawa air (aquifer) karena bersifat tidak lulus air (impermeable). Pada waktu musim hujan bersifat lembek dan pada musim kemarau berubah menjadi kering dan padat. Pada musim kemarau, juga memungkinkan terjadinya kebakaran.

Struktur punden berada di alam terbuka pada suatu wilayah beriklim tropis dengan kelembaban lingkungan dan curah hujan relatif tinggi. Selain itu struktur tersebut terletak di atas bukit dengan kelerengan relatif terjal dan ditengarai sebagai daerah rawan longsor. Dalam rentang waktu yang sangat panjang, keadaan seperti ini berpotensi menimbulkan dampak yang kurang menguntungkan bagi kelestarian srtuktur punden dan lingkungannya. Dari data lapangan yang ada dapat dilihat bahwa kerusakan struktur punden tidak hanya terjadi dalam bentuk elemen batu yang terlepas dan tersebar di halaman hingga ke lereng bukit dan di desa-desa sekitarnya, tapi juga menyangkut susunan batu-batu. Di samping itu, kondisi bahan penyusun struktur punden pada umumnya juga sudah banyak mengalami proses pelapukan sehingga keadaannya banyak yang aus, mengelupas dan rapuh serta ditumbuhi mikro organisme.

\section{Bencana Akibat Ulah Manusia: Pemanfaatan Lahan Yang Tidak Terpola}

Terdapat dua permasalahan pokok perilaku manusia kekinian yang terkait dengan Situs Gunung Padang. Pertama, terkait dengan pemanfaatan lahan karena belum maksimalnya pembebasan lahan sehingga sebagian lahan Gunung Padang masih merupakan milik pribadi. Hal ini mengakibatkan bagian lahan Situs Gunung Padang, yang seharusnya menjadi area konservasi, banyak didirikan warung. Kedua, sampai sekarang belum ada usaha pengembangan kepariwisataan di dekat Situs Gunung Padang maka kunjungan wisatawan selama ini hanya tertumpuk di Situs Gunung Padang. Jumlah pengunjung yang cukup tinggi merupakan salah satu indikator yang baik untuk bidang kepariwisataan apabila dikelola dengan baik dan tepat, tetapi apabila belum dikelola dengan benar maka akan menjadi masalah yang sangat sulit untuk dibenahi mengingat lokasi atau obyek kunjungannya merupakan produk budaya masa lalu yang tidak dapat diperbaharui (unnewrable), rentan kondisinya, dan jumlahnya sangat terbatas.

Berdasarkan pengamatan lapangan yang dilakukan dapat dilihat berbagai dampak kunjungan wisata dan belum siapnya Situs Gunung Padang menjadi objek kunjungan 
wisata dengan angka kunjungan ribuan orang setiap minggunya dan tidak tertutup kemungkinan akan terjadi setiap hari di masa yang akan datang.

Dengan demikian, besarnya arus kunjungan wisatawan telah memberikan berbagai dampak negatif pada Situs Gunung Padang. Berkaitan dengan pemanfaatan Situs Gunung Padang sebagai obyek pariwisata, dalam Undang-Undang No. 11 Tahun 2010 tentang Cagar Budaya pasal 86 disebutkan bahwa pemanfaatan yang dapat menyebabkan terjadinya kerusakan wajib didahului dengan kajian, penelitian, dan/atau analisis dampak lingkungan. Semua hal tersebut selama ini belum pernah dilakukan di Situs Gunung Padang. Dampak negatif dari hal tersebut adalah kerusakan terhadap struktur dan lahan Situs Gunung Padang.

Beberapa bentuk kerusakan struktur sebagai dampak dari kunjungan masyarakat ke Situs Gunung Padang karena tidak tersedianya lahan bagi pengunjung yang kemudian pengunjung hanya bisa melakukan aktivitasnya di lahan situs, sehingga akhirnya menimbulkan dampak negatif terhadap kelestarian Situs Gunung Padang, disamping kerusakan yang terjadi secara alamiah karena konstruksi Situs Gunung Padang berbentuk punden berundak tersebut dibangun dengan teknologi sederhana. Susunan balok-balok batu tersebut tampak sangat sederhana yaitu hanya terdiri satu baris batu yang disusun sedemikian rupa tanpa pola ikat dan diletakkan di atas tanah tanpa perkuatan.

Berdasarkan pengamatan lapangan dapat diketahui bahwa kerusakan struktur dan lingkungan Situs Gunung Padang disebabkan oleh dua faktor yaitu faktor internal dan faktor eksternal. Kerusakan karena faktor internal antara lain disebabkan karena lemahnya konstruksi Situs Gunung Padang. Balok-balok batu disusun tanpa pola ikat. Hal itu juga dipengaruhi oleh tanah dasar berupa tanah lempung. Jenis tanah tersebut pada saat kering memiliki kekuatan yang cukup untuk mendukung struktur, akan tetapi bila terkena air hujan dapat melemahkan daya dukung tanah dasar serta mudah tererosi. Faktor tersebut diperparah oleh posisi situs yang dikelilingi oleh lereng terjal (kemiringan $30^{\circ} \mathrm{s} / \mathrm{d} 50^{\circ}$ ). Kerusakan struktur karena faktor eksternal antara lain dipengaruhi oleh kondisi lingkungan mikro seperti disebabkan oleh fluktuasi suhu udara, kelembaban lingkungan, tingginya curuh hujan, serta desakan akar pohon-pohon besar yang tumbuh di halaman teras. Selain itu, berbagai aktivitas manusia seperti penebangan pohon, corat-coret, dan pola tanam masyarakat di bagian lereng bukit (vandalism) dapat disimpulkan sebagai faktor eksternal yang kemudian ikut mendorong terjadinya kerusakan dari struktur punden berundak Gunung Padang. Kedua faktor tersebut telah menimbulkan terjadinya proses kerusakan sebagai berikut:

a. Proses mekanis; Proses mekanis adalah proses kerusakan yang disebabkan oleh adanya penyebaran tekanan atau penyebaran gaya yang tidak seimbang pada struktur punden. Proses ini mengakibatkan sebagian besar punden berundak strukturnya miring, melesak, runtuh, bahkan terjadi longsor di bagian dinding teras 1 sisi utara. Kerusakan struktur karena proses mekanis diperkirakan mencapai $80 \%$. 
b. Proses fisis : Proses fisis adalah proses pelapukan yang disebabkan oleh adanya interaksi fisik pada bahan penyusun struktur punden. Proses ini mengakibatkan sebagian kecil bahan struktur punden terkikis, retak halus, dan aus. Kerusakan struktur karena proses fisis diperkirakan mencapai $10 \%$.

c. Proses khemis: Proses khemis adalah proses pelapukan yang disebabkan oleh adanya reaksi kimiawi pada bahan penyusun struktur punden. Proses semacam ini hampir tidak ditemukan atau tidak terjadi pada struktur punden.

d. Proses biotis; Proses biotis adalah proses pelapukan yang disebabkan oleh adanya pertumbuhan jasad renik (micro organism) pada bahan penyusun struktur punden. Proses ini mengakibatkan sebagian besar permukaan batu ditumbuhi jamur kerak dan ganggang. Kerusakan struktur karena proses biotis diperkirakan mencapai $50 \%$.

\section{SIMPULAN}

Dapat disimpulkan bahwa pada konstruksi punden berundak Gunung Padang yang dibangun dengan pola-pola susun tertentu merupakan hasil proses dialektika antara individu atau masyarakat dengan lingkungannya. Dalam hal ini, pembangunan punden berundak di puncak Gunung Padang tersebut selain dilakukan unuk pemenuhan kebutuhan sacral pada masa lalu, juga proses pembangunanya telah mempertimbangkan ancaman kebencanaan yang sering terjadi di lingkungan Gunung Padang pada masa lalu. Kearifan lokal yang diterapkan dalam konstruksi tersebut dapat diartikan sebagai respon terhadap kondisi lingkungannya, serta daya antisipatif masyarakat terhadap perubahan yang ditimbulkan oleh pengaruh lingkungan.

Seiring dengan perjalanan waktu, ternyata ancaman terhadap punden berundak Gunung Padang tidak hanya terjadi karena pengaruh alam akan tetapi juga terjadi karena perilaku manusia yang kemudian hadir di Gunung Padang baik hadir sebagai pemukim yang kemudian melalkukan aktivitas pertanian di lingkungan situs yang rawan akan longsor, tetaapi juga arus kunjungan wisatawan yang tidak atau belum diantisipasi dengan

daya dukungnya. Hal ini kemudian memperparah dan mengacam kelestarian Situs Gunung Padang.

\section{DAFTAR PUSTAKA}

Bronto, Sutikno, dkk. (2012). Laporan Penelitian Dan Pemetaan Geologi Gunung Padang, Gunung Lalakon, Dan Gunung Sadahurip, Jawa Barat. Bandung: Badan Geologi.

Bronto, Sutikno dan Billy S. Langi. (2016). Geologi Gunung Padang dan Sekitarnya., Kabupaten Cianjur-Jawa Barat. Jurnal Geologi Dan Sumberdaya Miner pal. Pusat Survei Geologi, 37-49. Bandung: Badan Geologi.

Herman DZ. (2017). Pengenalan Geologi Lingkungan Wilayah G.Padang Sebagai Penunjang Laporan Studi Arkeologi dan Geologi G.Padang, Kabupaten Cianjur, Jawa Barat. Bandung: BP2D. 
Krom, N. J. (1915). Rapporten Oudheidkundige Dienst In Nederlandsch-Indie (ROD) 1914. UItgegeven door het Bataviasch Genootschap van Kunsten en Wetenschappen. Albrech \& Co.

Verbeek. R. D. M (1891). Verhandelingen van Het Bataviaasche Genootschap der Kunsten en Wetenschappen Deel XLVI. Batavialandsbukerij.

Skempton, A. (1969). The consolidation of clays by gravitational compaction. Quart.Journ.Geol.Sc., 124.

Sukendar, H. (1985). Album Peninggalan Megalitik Kabupaten Cianjur. Jakarta: Pusat Penelitian Arkeologi Nasional dan Museum National D'histoire Naturelle.

Yondri, L. (2016). Situs Gunung Padang, Kebudayaan, Manusia, dan Lingkungan (R. S. Fitriani (ed.); Pertama). Bandung: CV. Semiotika.

Yondri, L. (2019). Manusia dan Budaya Prasejarah di Gunung Pawon (Dr. Iwan Hermawan (ed.); Pertama). Bandung: Balai Arkeologi Jawa Barat.

\section{HASIL DISKUSI}

\section{Masukan}

1. Sonny Wibisono (Pusat Penelitian Arkeologi Nasional)

Perlu panduan praktis seperti leflet bagi pengunjung. Tidak hanya Memuat sirkulasi pengunjung juga penduan tidak hanya memberi penjelasan tentang ojek penting di Gunung Padang, tetapi juga memuat mana yang tidak oleh di lakukan pengunjung.

\section{Tanggapan}

1. Penulis pernah membuatkan materi tentang Situs Gunung Padang yang kemudian diperbanyak oleh Balai Pengelolaan Cagar Budaya, Sejarah dan Nilai Tradisional, Propinsi Ja-wa Barat karena jumlah cetakannya terbatas lalu habis dan tidak pernah di cetak lagi.

2. Materi tentang Gunung Padang tersebut juga pernah disampaikan ke Pemerintah Kabupaten Cianjur untuk dicetak lagi dan sebagai bagian dari informasi yang diberikat saat kun-jungan. Sayangnya hal tersebut belum dilakukan hingga kini. Setuju.

3. Terkait dengan tinginya jumlah pengunjung yang tidak selaras dengan daya dukung lahan dan bentuk struktur Situs Gunung Padang yang tersusun dari balok-balok batu yang disusun sederhana, untuk mengantisipasi perubahan yang diakibatkan oleh arus kunjungan ke depan perlu dibuat panduan do and donts untuk visitor. 